\section{Recovery of waste expanded polystyrene in lightweight concrete production}

The Mining-Geology-Petroleum Engineering Bulletin UDC: 624.01

DOI: 10.17794/rgn.2019.3.8

Original scientific paper

\author{
Gordan Bedeković́; ; Ivana Grčić; Aleksandra Anić Vučinić; Vitomir Premur ${ }^{2}$ \\ ${ }^{1}$ University of Zagreb, Faculty of Mining, Geology and Petroleum Engineering, Pierottijeva 6, 10000 Zagreb, Croatia \\ ${ }^{2}$ University of Zagreb, Faculty of Geotechnical Engineering, Hallerova 7, 42000 Varaždin, Croatia
}

\begin{abstract}
Polystyrene concrete, as a type of lightweight aggregate concrete, has been used in civil construction for years. The use of waste expanded polystyrene (EPS) as a fill material in lightweight concrete production is highly recommended from the point of view of the circular economy. Published data shows that an increase in the proportion of lightweight aggregates, i.e. EPS, results in a decrease in strength, bulk density and thermal conductivity of the concrete. Utilizing large quantities of waste EPS in non-structural polystyrene concrete production is particularly important. Unlike structural polystyrene concrete, according to the published papers, non-structural polystyrene concrete has not been investigated sufficiently. The purpose of this paper is to determine the influence of the ratios of the basic components in a concrete mixture on the bulk density and compressive strength of non-structural polystyrene concrete produced by utilizing waste EPS as a fill material. The test specimens, i.e. cubes with an edge length of $100 \mathrm{~mm}$ each, were prepared in laboratory conditions by varying the proportions of EPS, sand up to $600 \mathrm{~g}$ and cement ranging from $300 \mathrm{~g}$ to $450 \mathrm{~g}$ per specimen. Bulk density and compressive strength were determined for the test specimens. Laboratory research results show a dependence of the component ratio on the bulk density ranging from $360 \mathrm{~kg} / \mathrm{m}^{3}$ to $915 \mathrm{~kg} / \mathrm{m}^{3}$ and compressive strength ranging from $0.385 \mathrm{MPa}$ to $2.538 \mathrm{MPa}$.
\end{abstract}

\title{
Keywords:
}

waste expanded polystyrene, lightweight concrete, circular economy

\section{Introduction}

The aim of this research is to establish options for non-structural lightweight aggregate concrete production with the purpose of waste EPS disposal and to establish the principles of the dependence of cement, mineral fill material and waste granulated EPS proportions on the most important properties of concrete such as bulk density and compressive strength. This paper is focussed on polystyrene concrete investigations, prepared without additives, with a bulk density from 300 to 1000 $\mathrm{kg} / \mathrm{m}^{3}$.

Concrete is an artificial building material consisting of aggregates (70-80\%), binder (10-20\%), water and various additives. Stone, gravel and sand are used as an aggregate, while cement is generally used as a binder. By selecting a particular type of aggregate, determining its exact mass, as well as the cement-water ratio, and, if necessary, by adding additives, it is possible to produce concrete for each specific purpose. Taking into account that aggregate is one of the main components of concrete, the quality of the concrete depends on the quality

Corresponding author: Gordan Bedeković gordan.bedekovic@oblak.rgn.hr of the aggregate. Therefore, aggregate has to fulfill adequate requirements as a specific granulometric composition, approximately cubic shape of grains and must possess specific purity, regardless of the fact whether aggregate stone or gravel and sand are used (Salopek et al., 2002; Sobota et al., 2011; Kujundžić, et al. 2008; Yari and Bagherpour, 2018.). Taking into account its origin, an aggregate can be natural, unclassified, industrially produced and recycled, and according to its density, it is lightweight $\left(\rho<2000 \mathrm{~kg} / \mathrm{m}^{3}\right)$, normal weight $\left(2000<\rho<3000 \mathrm{~kg} / \mathrm{m}^{3}\right)$ or heavyweight $\left(\rho>3000 \mathrm{~kg} / \mathrm{m}^{3}\right)$.

The limited reserves of mineral resources, economic circumstances (Vorob'ev et al., 2017; Dychkovskyi et al., 2018) and environmental standards impose the rational use of primary (mineral) resources through urban mining, i.e. the transition from the linear to circular economy. The application of circular economy principles imposes the use of waste as a secondary resource, unlike waste disposal common in the past century.

Polystyrene is one of the most widely used plastics, mainly in its expanded form, under the brand name of Styropor or Styrofoam. Expanded polystyrene (EPS) contains approximately $2 \%$ of styrene, while the remaining $98 \%$ consists of pores filled with air. EPS is mostly used for thermal insulation systems or as a pack- 
aging material. Its thermal conductivity ranges from 0.03 to $0.04 \mathrm{~W} / \mathrm{mK}$ and depends on the bulk density ranging from 9 to $36 \mathrm{~kg} / \mathrm{m}^{3}$. Due to its wide use, large quantities of waste EPS are generated, while its low bulk density presents a huge problem, both during the use and disposal of EPS. Despite its low mass fraction in landfills, its volume is significant, in some countries even up to $7 \%$ (Kekanović et al., 2014). The UK produces 300 000 tonnes per year, occupying $38 \cdot 10^{6} \mathrm{~m}^{3}$ of landfill volume. Additionally, its large volume with low mass significantly increases the cost of recovery and transport. Every year, between 120 and 150 tonnes of waste EPS is collected in the Republic of Croatia, and millions of tonnes in the world (Herki et al., 2013). The company Tschanhenz \& Križaj d.o.o. from Markuševac carries out the recovery of EPS through the production of beads intended for polystyrene concrete production or compacting.

Concrete is a suitable product for the economically and environmentally acceptable disposal of various types of waste (Premur et al., 2018). Lightweight concrete is a multi-purpose material for construction, which offers a range of technical, economical and environment-enhancing and preserving advantages and is destined to become a dominant material for construction in the new millennium (Sadrmomtazi et al., 2013). Its main advantage is its low volumetric weight starting from $90 \mathrm{~kg} / \mathrm{m}^{3}$ (Schackow et al., 2014), and according to HR EN 206-1:2006 between $800 \mathrm{~kg} / \mathrm{m}^{3}$ and $2000 \mathrm{~kg} /$ $\mathrm{m}^{3}$. It is classified as a structural lightweight concrete with a compressive strength higher than $17 \mathrm{MPa}$ or a non-structural lightweight aggregate concrete with a compressive strength lower than $17 \mathrm{MPa}$ (Saradhi Babu et al., 2005). Non-structural concrete is widely used in building construction (Sadrmomtazi et al., 2012), mostly as an insulation material, i.e. for filling voids. In lightweight concrete production, an aggregate with uniform grain size is used to obtain air-filled cavities, resulting in lower bulk density and thermal conductivity. Cellular concrete is a type of lightweight concrete with a "spongy" structure with gas bubbles obtained by an injection or as a result of a chemical reaction. The lightweight concrete manufactured in this manner is called gas concrete or foamed concrete. Lightweight concrete can be produced by replacing the mineral aggregate with solid density mainly between $2500 \mathrm{~kg} / \mathrm{m}^{3}$ and $2800 \mathrm{~kg} / \mathrm{m}^{3}$ with a natural or artificial expanded aggregate with lower solid density. Concrete produced in this manner is called lightweight aggregate concrete (LAC).

EPS is also used in the production of polystyrene concrete, either as virgin beads or waste granulated EPS. Literature contains research results on various properties of green and hardened LAC, mostly on compressive strength in $86 \%$ of papers, and bulk density in $71 \%$ of papers (Vakhshouri and Nejadi, 2018). The research is mostly focussed on structural polystyrene concrete with a bulk density higher than $1000 \mathrm{~kg} / \mathrm{m}^{3}$. Lightweight aggregate concrete with a bulk density lower than $1000 \mathrm{~kg} /$ $\mathrm{m}^{3}$ with the addition of EPS as a fill material was investigated by Bagon, and Frondistou-Yannas. They investigated the samples of bulk density ranging from 650 to $800 \mathrm{~kg} / \mathrm{m}^{3}$ by inserting $425 \mathrm{~kg}$ to $505 \mathrm{~kg}$ of cement in 1 $\mathrm{m}^{3}$ of concrete (Bagon and Frondistou-Yannas, 1976). They measured the compressive strength fc ranging from 3.3 to $5.0 \mathrm{MPa}$ on 14 day old test specimens in the shape of cylinders. Chen and Fang (2009) produced concrete with a bulk density from $975 \mathrm{~kg} / \mathrm{m}^{3}$ to $983 \mathrm{~kg} /$ $\mathrm{m}^{3}$ with an EPS volume fraction of 55\%. The compressive strength of the samples reinforced by fibres was between 8.5 and 10.5 MPa. Saradhi Babu et al. (2005) carried out the experimental programme with concrete specimens by varying the proportion of a mineral fill material, fly ash and EPS beads, with the EPS volume fraction in the concrete varying from 0 to $66.5 \%$. They obtained concrete with a bulk density ranging from 582 to $984 \mathrm{~kg} / \mathrm{m}^{3}$ with 49 to $66.5 \%$ of volume filled with EPS beads, while the compressive strength of test specimens ranged from 1.1 to $3.83 \mathrm{MPa}$. Chen and Liu (2013) tested the samples of foamed concrete by varying the pore-EPS beads ratio. In their paper, polystyrene concrete with a bulk density of 400 and $800 \mathrm{~kg} / \mathrm{m}^{3}$ had the compressive strength of 1.58 and $7.79 \mathrm{MPa}$, respectively. Their research confirmed a significant influence of EPS content on compacting. It also confirmed that by combining the polystyrene concrete and aerated concrete, with an increase in the proportion of pores while maintaining density, insulation properties and strength were improved. They determined that the aforementioned specimens had a thermal conductivity of 0.15 and $0.3 \mathrm{~W} / \mathrm{mK}$, respectively. Herki et al. (2013) and Herki and Khatib (2016) replaced natural aggregate, in different ratios, with waste EPS beads stabilised with clay, with a bulk density of $457 \mathrm{~kg} / \mathrm{m}^{3}$. When they completely replaced natural aggregate with EPS, they obtained a strength of $4.56 \mathrm{MPa}$ with a bulk density of $1007 \mathrm{~kg} / \mathrm{m}^{3}$.

Kekanović et al. (2014) confirmed the possibility of obtaining polystyrene concrete with crushed waste EPS with a grain size smaller than $5 \mathrm{~mm}$. They established that it was easier to produce polystyrene concrete from waste EPS than from EPS virgin beads, and that the hardened concrete had better mechanical and insulation properties. They determined thermal conductivity of $0.0763 \mathrm{~W} / \mathrm{mK}$ for the concrete sample with a bulk density of $560 \mathrm{~kg} / \mathrm{m}^{3}$. Thermal conductivity of the samples obtained by combining the gas concrete and polystyrene concrete with the bulk density ranging from 300 to 330 $\mathrm{kg} / \mathrm{m}^{3}$ was determined by Wang and Fu (2013) with values ranging from 0.068 to $0.085 \mathrm{~W} / \mathrm{mK}$.

A large number of papers are related to lightweight aggregate concrete with a bulk density between 1000 and $2000 \mathrm{~kg} / \mathrm{m} 3$ with the possibility of adding fly ash (Park and Chisholm, 1999; Herki et al. 2013), silica fume (Ganesh Babu and Saradhi Babu 2003; Abd- 
ElAziz et al. 2017) rice husk ash and silica fume (Sadrmomtazi et al., 2012), or blast-furnace slag (Wang and Tsai, 2006). The mechanical properties of lightweight aggregate concrete are successfully improved by adding steel (Chen and Liu, 2004), glass (Herki and Khatib, 2016), or polymer fibres (Muravljov et al., 2000; Chen and Fang, 2009), and using stabilised polystyrene (SPS) (Herki and Khatib, 2016). The workability and the proportion of pores were frequently tested for green concrete, while compressive and tensile strength, bulk density, elastic modulus and other properties were tested for hardened concrete, on the test specimens of different sizes, shapes and age. The tests confirmed that, in addition to its basic components ratio, granulometric composition, waste EPS and placement operations (Chen and Liu, 2013), curing conditions (Ling and Teo, 2011) also influence the properties of lightweight aggregate concrete.

The influence of the size of EPS virgin beads was also investigated (Ganesh Babu and Saradhi Babu 2003; Liu and Chen, 2014; Miled et al., 2007, Ning and Chen 2014) and it was established that the size of beads was inversely proportional to the strength with equal bulk density. Based on published papers, all authors concluded that strength, bulk density and thermal conductivity of lightweight aggregate concrete decrease with an increase in lightweight aggregate fill proportion.

\section{Materials and methods}

Compressive strength and bulk density investigations were carried out on test cubes made of the following components: mineral fill material, cement as a binder, waste EPS and EPS wetting agent. The aforementioned components were used for the laboratory production of test specimens - the cubes with an edge length of 100 $\mathrm{mm}$. NexeSpecijal CEM II/A-M (S-V) $42.5 \mathrm{~N}$, i.e. mixed Portland cement, strength class $42.5 \mathrm{~N}$ was used as a binder. The chemical composition of cement is presented in Table 1, and granulometric composition in Figure 1. The sand of a local supplier, grain size class $4 \mathrm{~mm}$, was used for the preparation of test specimens. The

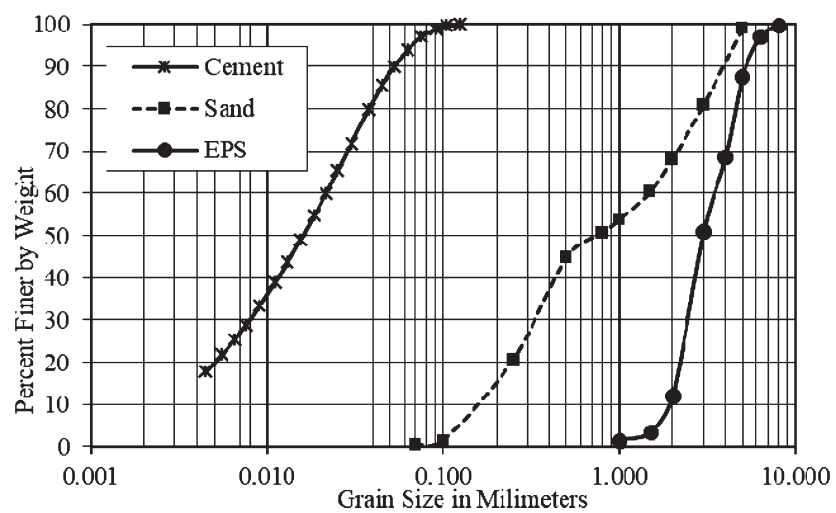

Figure 1: Granulometric composition of cement, sand and EPS

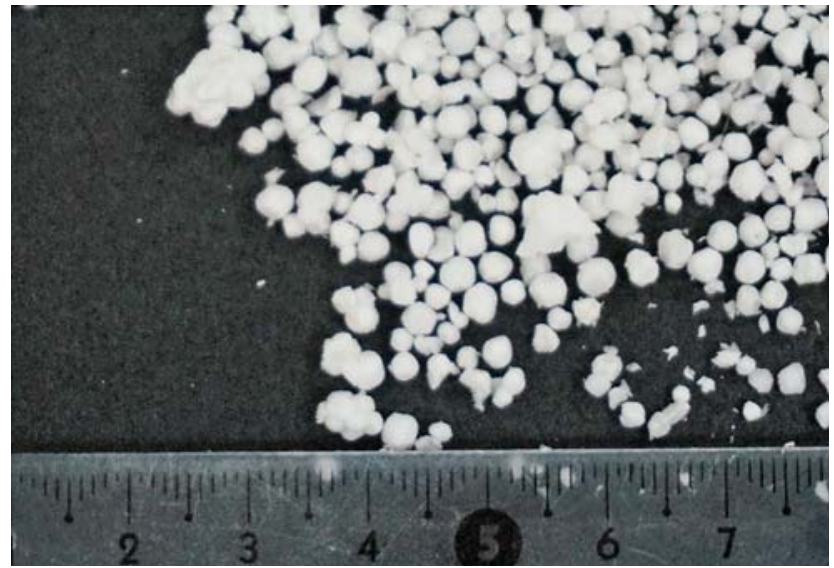

Figure 2: Granulated waste EPS

Table 1: Chemical composition of cement according to HRN EN 196-2:2013

\begin{tabular}{|l|c|}
\hline Component & Mass fraction, \% \\
\hline Loss of ignition, $\mathrm{L.o.i.}$ & 2.38 \\
\hline Corrected L.o.i. & 2.47 \\
\hline Sulphate, $\mathrm{SO}_{3}$ & 3.42 \\
\hline Insoluble residue, $\mathrm{HCl}$ and $\mathrm{Na}_{2} \mathrm{CO}_{3}$ & 3.92 \\
\hline Insoluble residue, $\mathrm{HCl}$ and $\mathrm{KOH}$ & 1.39 \\
\hline Sulfide, $\mathrm{S}^{2-}$ & 0.07 \\
\hline Manganese oxide, $\mathrm{MnO}$ & 0.32 \\
\hline Total silicium dioxide, $\mathrm{SiO}_{2}$ & 23.87 \\
\hline Iron (III) oxide, $\mathrm{Fe}_{2} \mathrm{O}_{3}$ & 2.61 \\
\hline Aluminium oxide, $\mathrm{Al}_{2} \mathrm{O}_{3}$ & 6.54 \\
\hline Calcium oxide, $\mathrm{CaO}$ & 56.40 \\
\hline Magnesium oxide, $\mathrm{MgO}_{3}$ & 2.96 \\
\hline Chlorine, $\mathrm{Cl}$ & 0.022 \\
\hline Sodium oxide, $\mathrm{Na}_{2} \mathrm{O}$ & 0.32 \\
(according to 4.5.19.4.2.) & 0.85 \\
\hline Potassium oxide, $\mathrm{K}_{2} \mathrm{O}$ & 0.88 \\
\hline Na ${ }_{2} \mathrm{O}$ (according to 4.5.19.6.2.) & 1.69 \\
\hline Carbon dioxide, $\mathrm{CO}_{2}$ & \\
\hline
\end{tabular}

Table 2: Mineral composition of sand, grain size class $-4 \mathrm{~mm}$

\begin{tabular}{|l|c|}
\hline Component & Mass fraction, \% \\
\hline Quartzite & 37.67 \\
\hline Quartzite & 36.03 \\
\hline Feldspar & 6.70 \\
\hline Igneous rock & 6.56 \\
\hline Siltstone & 2.13 \\
\hline Sandstone & 2.03 \\
\hline Quartz with Feldspar & 2.03 \\
\hline Garnets & 2.01 \\
\hline Chalcedony & 1.56 \\
\hline Mica & 0.76 \\
\hline Dolomite & 0.73 \\
\hline Limestone & 0.55 \\
\hline Amphibolite & 0.45 \\
\hline Opaque minerals & 0.39 \\
\hline Pyroxene & 0.20 \\
\hline Amphibole & 0.20 \\
\hline
\end{tabular}


Table 3: Test cube preparation list

\begin{tabular}{|c|c|c|c|c|c|c|}
\hline \multirow{2}{*}{ Series } & \multirow{2}{*}{ Sample no. } & Sand $<4 \mathrm{~mm}$ & Cement & EPS & Water & \multirow{2}{*}{$\mathrm{w} / \mathrm{c}$} \\
\hline & & $\mathrm{g}$ & $\mathrm{g}$ & $\mathrm{g}$ & $\mathrm{ml}$ & \\
\hline \multirow{4}{*}{ I. Series } & 1 & 0 & 300 & 22.0 & 165.0 & 0.55 \\
\hline & 2 & 0 & 350 & 22.0 & 192.5 & 0.55 \\
\hline & 3 & 0 & 400 & 22.0 & 220.0 & 0.55 \\
\hline & 4 & 0 & 450 & 22.0 & 247.5 & 0.55 \\
\hline \multirow{4}{*}{ II. Series } & 5 & 200 & 300 & 22.0 & 165.0 & 0.55 \\
\hline & 6 & 200 & 350 & 22.0 & 192.5 & 0.55 \\
\hline & 7 & 200 & 400 & 22.0 & 220.0 & 0.55 \\
\hline & 8 & 200 & 450 & 22.0 & 247.5 & 0.55 \\
\hline \multirow{4}{*}{ III. Series } & 9 & 400 & 300 & 22.0 & 165.0 & 0.55 \\
\hline & 10 & 400 & 350 & 22.0 & 192.5 & 0.55 \\
\hline & 11 & 400 & 400 & 22.0 & 220.0 & 0.55 \\
\hline & 12 & 400 & 450 & 22.0 & 247.5 & 0.55 \\
\hline \multirow{4}{*}{ IV. Series } & 13 & 600 & 300 & 22.0 & 165.0 & 0.55 \\
\hline & 14 & 600 & 350 & 22.0 & 192.5 & 0.55 \\
\hline & 15 & 600 & 400 & 22.0 & 220.0 & 0.55 \\
\hline & 16 & 600 & 450 & 22.0 & 247.5 & 0.55 \\
\hline
\end{tabular}
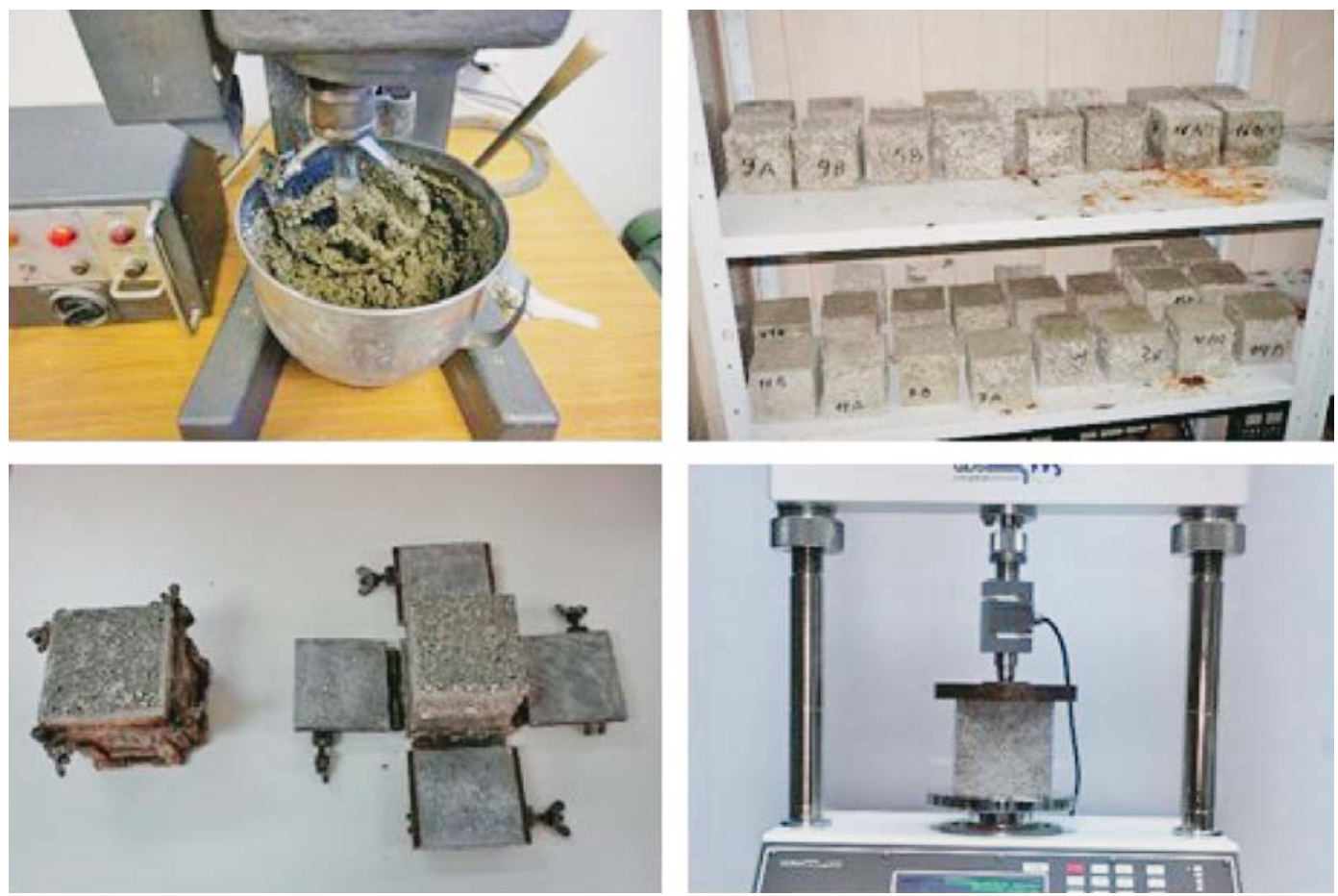

Figure 3: Preparation of concrete mixture, preparation and curing of concrete cubes, and compressive strength testing

granulometric and mineral composition of the sand are presented in Figure 1 and Table 2, respectively. Waste granulated EPS was obtained by crushing the mixture of waste insulation EPS and polystyrene packaging (see Figure 2). Since the EPS granulometric composition significantly influences concrete strength and bulk density, the granulometric composition was determined by sieving (see Figure 1). The density of beads was not determined since the material was a mixture of different types of waste EPS. The bulk density of waste EPS beads in a scattered condition was $14.5 \mathrm{~kg} / \mathrm{m}^{3}$. Stigodur $\mathrm{D}$ was used as an EPS wetting agent in the preparation of test cubes.

Concrete test cubes, with an edge length of $100 \mathrm{~mm}$, were prepared under laboratory conditions. Due to unknown concrete placement conditions, it was not possible to determine the exact quantity of a necessary mixture, therefore, the mixture of a volume larger than $1 \mathrm{dm}^{3}$ was prepared. The mixture was put in moulds, and the excess mixture was removed after weighing. Four series 
of specimens were prepared: without sand, and with 200, 400 and $600 \mathrm{~g}$ of sand per specimen. In each series test specimens with $300,350,400$ and $450 \mathrm{~g}$ of cement per specimen were prepared. In each mixture $22 \mathrm{~g}$ of EPS and $5 \mathrm{ml}$ of EPS casting agent were added. The water-cement ratio was 0.55 during the preparation of all test cubes. A test cube preparation list is presented in Table 3.

The EPS substance was weighed and then put in a planetary mixer of 5.01 volume and mixed with a corresponding quantity of water and $5 \mathrm{ml}$ of EPS wetting agent. After three minutes of mixing, sand was added and the mass was mixed for three more minutes. Then cement was added and the mass was mixed for five more minutes. The fresh cement mixture was put into metal moulds manually, according to EN 12390-2:2009. The mixture was put in moulds manually due to the possibility of an EPS segregation during compacting by vibration (Sayadi et al., 2016; Herki et al., 2013). Since waste EPS is heterogenous, the shape of its beads is irregular, its density is not defined and the volume of pores in the concrete specimens are unknown, and so the exact volume of EPS in the specimens was not determined.

The concrete cubes were removed from the moulds after 24 hours (see Figure 3), their mass was determined, and they were cured in air filled with water vapour at a temperature of $20^{\circ} \mathrm{C}$ until compressive strength testing took place. Although Xu et al. (2015) established that in the case of different EPS proportions the water-cement ratio influences the strength, a water-cement ratio of 0.55 was used in the preparation of all test cubes. For each test cube preparation list, three test cubes were made. Compressive strength testing was carried out on 28 days old test cubes, on a load frame manufactured by GDS Instruments, type: GDSLF50, according to EN 12390-3:2009 (see Figure 3). Bulk density was determined by measuring the dimensions of the test cubes according to EN 12390-7:2009.

\section{Results and discussion}

Research results show that polystyrene concrete can be produced with no difficulties with defined preparation instructions. The sections of specimens 1 and 16 (see Figure 4) show that in a specimen of polystyrene concrete with a lower portion of cement and without sand, a larger space is filled by EPS than in specimen 16, which contains sand and a higher proportion of cement (see Figure 4). EPS beads of an irregular shape (a), cement binder (b), pores filled with air (c) and coarse grains of sand (d) are clearly visible in Figure 4.

The results of bulk density depending on the mass fraction of individual components are presented in Figure 5. The bulk density of the test cubes was between $360 \mathrm{~kg} / \mathrm{m}^{3}$ for specimen 1 and $915 \mathrm{~kg} / \mathrm{m}^{3}$ for specimen 16 , i.e. within the aimed range of the research. The specimens from series 1 , i.e. the specimens prepared without

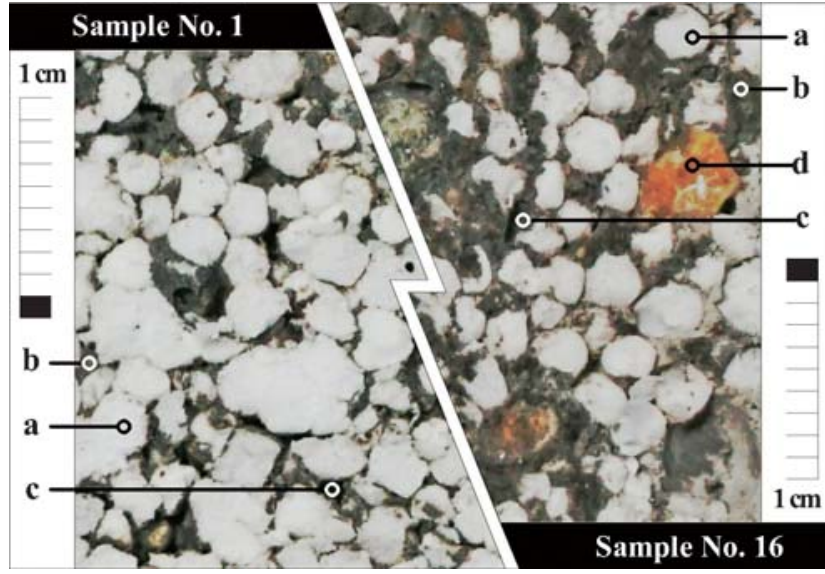

Figure 4: Sections of concrete cubes: a- EPS beads, b-cement, c-pores filled with air, d-grains of sand).

sand, have the lowest bulk density ranging from 360 to $480 \mathrm{~kg} / \mathrm{m}^{3}$. The specimens from series 4 , i.e. the specimens with the highest mass fraction of sand have the highest bulk density ranging from 735 to $915 \mathrm{~kg} / \mathrm{m}^{3}$.

The compressive strength of the polystyrene concrete cubes fc increases, as expected, when the mass fraction

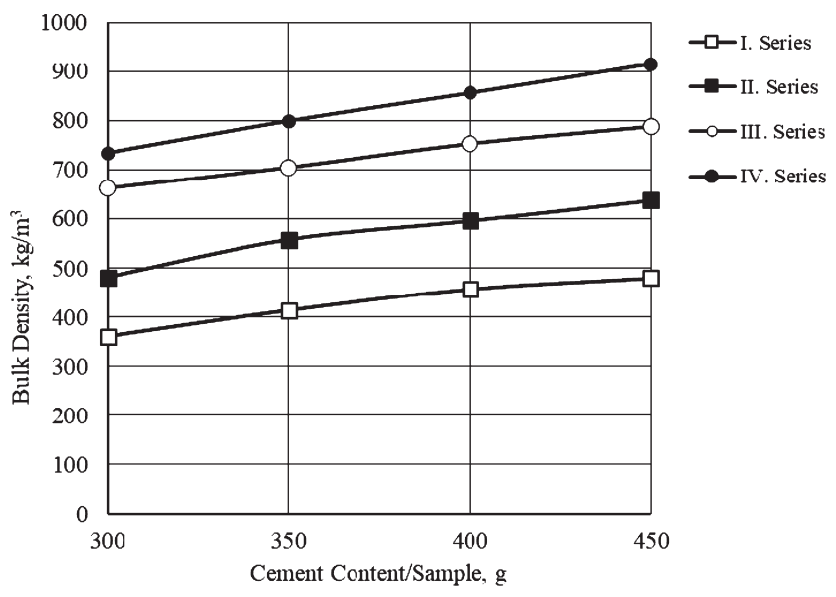

Figure 5: Dependence of bulk density on cement and sand proportion

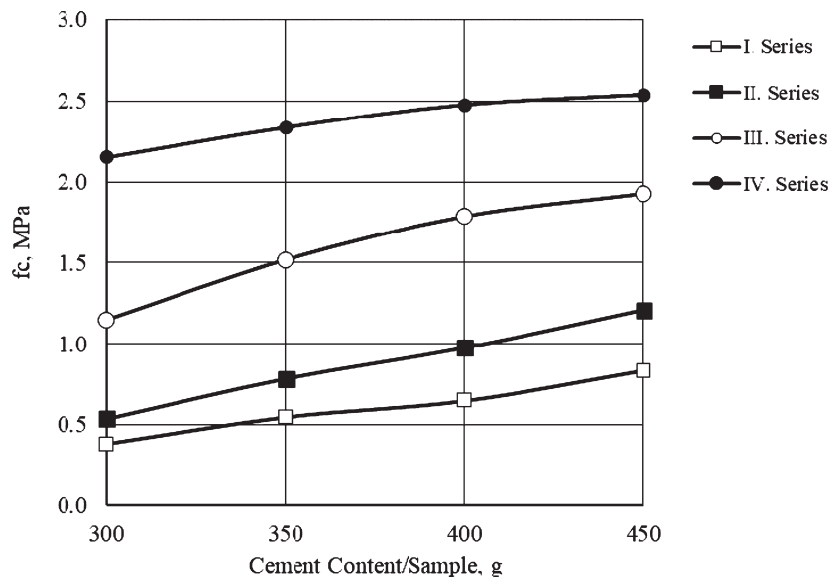

Figure 6: Dependence of compressive strength $\mathrm{fc}$ on cement and sand proportion 


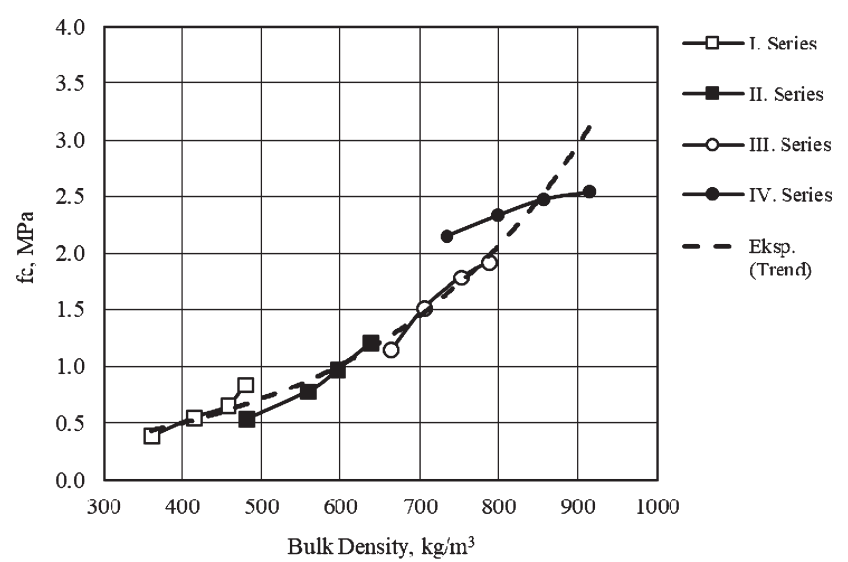

Figure 7: Dependence of strength and bulk density of specimens of different series

of sand and cement increases, which can be concluded from the diagram in Figure 6. As expected, the specimens from series 1, i.e. the specimens without sand, have the lowest strength ranging from 0.385 to 0.883 $\mathrm{MPa}$. The specimens from series 4 , i.e. the specimens with the highest mass fraction of sand, have the highest strength ranging from 2.150 to $2.538 \mathrm{MPa}$.

The results presented in Figures 5 and $\mathbf{6}$ present the arithmetic mean of measurements on three specimens of identical preparation. If the dependence of strength on bulk density is observed, as presented in Figure 6, a more or less increasing linear trend for strength with bulk density can be observed. The curves of series 1 and 2 are of a concave shape, i.e. the strength increases faster with an increase in cement proportion than in the case of the specimens from series 4 and 5.

The results presented in diagrams in Figures 5 and 6 show the expected increasing trends for bulk density and strength with an increase in sand and cement proportions (Vakhshouri and Nejadi, 2018). The slopes of the lines that present the dependence of bulk density on the cement proportion (see Figure 5), indicate an increase in bulk density with an increase in cement proportion, while the position of the curves indicates an increase in bulk density with an increase in sand proportion. It is expected that the dependence of bulk density on cement proportion will be linear in the diagram with linear measurements on axes, but the deviation from the linear dependence is observed. The deviation from the linear dependence of bulk density on cement and sand proportion can be attributed to the modification of properties of green concrete mixture, as well as to the possibility of compacting (Xu et al., 2015), therefore, to bulk density. With an increase in sand proportion, the curves are transformed into lines. With the approximation of individual curves with a straight line, the correlation coefficient increases from 0.9657 for series 1 to 0.9978 for series 4 . Figure 6 shows that the lines of series 1 and series 2 are closer than other curves which indicates the non-linear increase in strength with an increase in sand proportion.
Data on the dependence of bulk density and individual components proportion have higher values if they are observed in the context of realized strength, as presented in Figure 7. The trend line of all measured values can be approximated by an exponential curve with a correlation coefficient of 0.9496 . The curve of series 4 shows the highest deviation from the general trend line. Based on the presented data, it can be concluded that the equal range of strength values can be achieved with different sand-cement ratio. In the case of lower sand proportion, the curves of series 1 and series 2 overlap for identical strength. Series 3, even with $450 \mathrm{~g}$ per specimen (specimen 12) cannot obtain the strength of concrete of series 4 with only $300 \mathrm{~g}$ of cement (specimen 13). The bulk density of specimens 12 and 13 exceed the bulk density of specimen 14 of series 4. Varying the water-cement factor would probably influence the compaction of concrete; therefore, it would probably influence measurement results.

\section{Conclusions}

Based on the obtained data, it is established that a non-structural polystyrene concrete can be produced by using waste granulated EPS.

- The strength and bulk density of polystyrene concrete increases with an increase in the sand and cement proportion.

- Within the tested range of sand and cement proportions, dry bulk density of the concrete cubes ranging from 360 to $915 \mathrm{~kg} / \mathrm{m}^{3}$ with strength ranging from 0.385 to $2.538 \mathrm{MPa}$ were determined.

- The dependence of the increase in the proportion of volumetric weight on sand and cement proportion could be approximated by straight lines, and the dependence of the increase in strength with an increase in volumetric weight by an exponential curve.

- Within individual ranges of testing, the polystyrene concrete of equal bulk density and compressive strength can be produced with different sand and cement proportions. It is recommended to continue the research of thermal and acoustic properties of the tested polystyrene concrete.

\section{References}

Abd-ElAziz, M.A., Faried A.S., Kamel, M.M.A. (2017): Influence of Silica Fume Incorporation on the Fresh, Thermal and Mechanical Properties of Expanded Polystyrene (EPS) Foamed Concrete. American Journal of Civil Engineering. 5, 3, 188-195.

Bagon, C., Frondistou-Yannas, S. (1976): Marine Floating Concrete Made with Polystyrene Expanded Beads. Magazine of Concrete Research, 28, 97, 225-229.

Chen, B., Liu, N. (2013): A novel lightweight concrete-fabrication and its thermal and mechanical properties. Construction and Building Materials, 44, 691-698 
Chen, B., and C. Fang. (2009): Contribution of Fibres to the Properties of EPS Lightweight Concrete. Magazine of Concrete Research, 61, 9, 671-678.

Chen, B., Liu, J. (2004): Properties of lightweight expanded polystyrene concrete reinforced with steel fiber. Cement and Concrete Research, 34, 1259-1263.

Dychkovskyi, R., Vladyko, O., Maltsev, D., Cáceres Cabana, E. (2018): Some aspects of the compatibility of mineral mining technologies. The Mining-Geology-Petroleum Engineering Bulletin (Rudarsko-geološko-naftni zbornik), $33,4,73-82$.

EN 12390-2:2009: Testing hardened concrete - Part 2: Making and curing specimens for strength tests.

EN 12390-3:2009: Testing hardened concrete - Part 3: Compressive strength of test specimens.

EN 12390-7:2009: Testing hardened concrete - Part 7: Density of hardened concrete.

EN 206-1:2006: Concrete - Part 1: Specification, performance, production and conformity.

HRN EN 196-2:2013: Metode ispitivanja cementa - 2. dio: Kemijska analiza cementa (EN 196-2:2013)

Ganesh Babu, K., Saradhi Babu, D. (2003): Behaviour of lightweight expanded polystyrene concrete containing silica fume. Cement and Concrete Research, 33, 755-762.

Herki, B.M.A, Khatib, J.M. (2016): Structural behaviour of reinforced concrete beams containing a novel lightweight aggregate. International Journal of Structural Engineering, 7, 1, 1-30.

Herki, B.A. Khatib J.M., Negim, E.M. (2013): Lightweight Concrete Made from Waste Polystyrene and Fly Ash. World Applied Sciences Journal, 21, 9, 1356-1360.

Kekanović, M., Kukaras, D., Čeh, A., Karaman, G. (2014): Lightweight Concrete with Recycled Ground Expanded Polystyrene Aggregate. Tehnički vjesnik 21, 2, 309-315.

Kujundžić, T., Bedeković, G., Kuhinek, D. and Korman, T. (2008): Impact of rock hardness on fragmentation by hydraulic hammer and crushing in jaw crusher. The MiningGeology-Petroleum Engineering Bulletin (Rudarskogeološko-naftni zbornik), 20, 1, 83-90.

Ling, I.H., Teo, D.C.L. (2011): Properties of EPS RHA lightweight concrete bricks under different curing conditions. Construction and Building Materials, 25, 3648-3655.

Liu, N., Chen, B. (2014): Experimental study of the influence of EPS particle size on the mechanical properties of EPS lightweight concrete. Construction and Building Materials, 68, 227-232.

Miled K., Sab, K., Le Roy, R. (2007): Particle size effect on EPS lightweight concrete compressive strength: Experimental investigation and modelling. Mechanics of Materials. 39, 222-240.

Muravljov, M.A., Jevtić D.Lj., Zakoć D.M. (2000): Properties of Cement Based Composite Made with Expanded Polystyrene Grains and Polypropylene Fibres. Hemijska Industrija. 54, 11, 501-504.

Ning, L., Chen, B. (2014): Experimental Study of the Influence of EPS Particle Size on the Mechanical Properties of EPS Lightweight Concrete. Construction and Building Materials, 68, 227-232.
Premur, V., Anić Vučinić, A., Melnjak, I., Radetić, L. (2018): The Possibility of Using Non-Metal Fraction from Printed Circuit Boards in Pavement Manufacturing. Environmental Engineering and Management Journal, 17, 11, 2719-2729.

Sadrmomtazi, A., Sobhani, J., Mirgozar, M.A. (2013): Modeling compressive strength of EPS lightweight concrete using regression, neural network and ANFIS. Construction and Building Materials, 42, 205-216.

Sadrmomtazi, A., Sobhani, J., Mirgozar, M. A., and Najimi M. (2012): Properties of Multi-strength Grade EPS Concrete Containing Silica Fume and Rice Husk Ash. Construction and Building Materials, 35, 211-219.

Salopek, M., Sobota, I., Bedeković, G. (2002): Constructional features and efficiency of vertical impact shaft. The Mining-Geology-Petroleum Engineering Bulletin (Rudarskogeološko-naftni zbornik), 14, 1, 65-75.

Sayadi, A.A., Tapia, J.V., Neitzert T.R., Clifton, G.C. (2016): Effects of expanded polystyrene (EPS) particles on fire resistance,thermal conductivity and compressive strength of foamed concrete. Construction and Building Materials, $112,716-724$.

Schackow, A., Effting, C., Folgueras, M.V, Güths, S., Mendes, G.A. (2014): Mechanical and thermal properties of lightweight concreteswith vermiculite and EPS using air-entraining agent. Construction and Building Materials, 57, 190-197.

Saradhi Babu, D., Ganesh Babu, K., Wee, T.H. (2005): Properties of lightweight expanded polystyrene aggregate concretes containing fly ash. Cement and Concrete Research, $35,1218-1223$.

Sobota, I., Salopek, B., Bedeković, G. and Kutlić, A. (2011): Possibility of beneficiation of silica sand from the Croatian deposits using attrition scrubbing. The Mining-GeologyPetroleum Engineering Bulletin (Rudarsko-geološkonaftni zbornik), 23, 1, 53-66.

Vakhshouri, B., and Nejadi, S. (2018): Review on the mixture design and mechanical properties of the lightweight concrete containing expanded polystyrene beads. Australian Journal of Structural Engineering, 19, 1, 1-23, DOI: $10.1080 / 13287982.2017 .1353330$

Vorob'ev, A., Chekushina, T. \& Vorob'ev, K. (2017): Russian national technological initiative in the sphere of mineral resource usage. The Mining-Geology-Petroleum Engineering Bulletin (Rudarsko-geološko-naftni zbornik), 32, 2, 1-8.

Wang, H.Y., Tsai, K.C. (2006): Engineering properties of lightweight aggregate concrete made from dredged silt. Cement and Concrete Composites, 28, 481-485.

Wang, H., Fu, D.G. (2013): Experimental Study of Porous Concrete Material Thermal Insulation Material Lightweight Polystyrene Particles. Applied Mechanics and Materials, 357, 1053-1061.

Xu, Y., Jiang, L., Xu, J., Chu, H., Li, Y. (2015): Prediction of compressivestrength and elastic modulusof expanded polystyrenelightweight concrete. Magazine of Concrete Research, 67, 17, 954-962.

Yari, M., Bagherpour, R. (2018): Investigating an innovative model for dimensional sedimentary rock characterization using acoustic frequency analysis during drilling. The Mining-Geology-Petroleum Engineering Bulletin (Rudarsko-geološko-naftni zbornik), 40, 17-25. 


\section{SAŽETAK}

\section{Oporaba otpadnoga stiropora izradom lakoga betona}

Stiroporbetoni, kao vrsta lakoagregatnih betona, u gradnji se koriste već niz godina. Sa stajališta kružne ekonomije, od interesa je korištenje otpadnoga ekspandiranog polistirena (EPS) kao punila u njihovoj proizvodnji. Iz dostupnih podataka lako je uočiti kako s povećanjem udjela lakih agregata, odnosno EPS-a, betonima opadaju čvrstoća, zapreminska masa i toplinska vodljivost. Posebno je važna izrada nekonstrukcijskih stiroporbetona zbrinjavanjem što veće količine otpadnoga EPS-a. Za razliku od konstrukcijskih stiroporbetona, a prema dostupnoj literaturi, nekonstrukcijski nisu dovoljno istraženi. Svrha je ovoga rada utvrđivanje zakonitosti udjela osnovnih sastojaka betona na zapreminsku masu i tlačnu čvrstoću nekonstrukcijskoga stiroporbetona načinjenoga korištenjem otpadnoga EPS-a kao punila. U laboratorijskim uvjetima izrađena su probna tijela, kocke stranica $100 \mathrm{~mm}$, variranjem udjela EPS-a, zatim dodavanjem pijeska do 600 g i cementa od 300 do 450 g. Probnim tijelima određene su zapreminske mase i tlačne čvrstoće. Rezultati laboratorijskih istraživanja pokazali su ovisnost udjela sastojaka na zapreminske mase koje variraju u rasponu do 360 do $915 \mathrm{~kg} / \mathrm{m}^{3}$ i tlačne čvrstoće u rasponu od o,385 do 2,538 MPa.

\section{Ključne riječi:}

otpadni ekspandirani polistiren, lakoagregatni beton, kružno gospodarstvo

\section{Authors contribution}

Gordan Bedeković, (PhD, Full Professor, mining engineer) carried out the analysis of production, use and properties of standard and lightweight concrete. Based on the published results on the properties of polystyrene concrete and on his own results presented in this paper, he made conclusions on the influence of binders, filling materials and waste EPS proportions on the properties of polystyrene concrete. Ivana Grčić, (PhD, Assistant Professor, chemical engineer), based on the published data, analysed production, properties and use of EPS, and its possible role in the production of polystyrene concrete. Aleksandra Anić Vučinić, (Ph.D., Associate Professor, food engineer), analysed the possibility of the disposal waste EPS by applying the principles of circular economy. Vitomir Premur, (Ph.D., Senior Lecturer, mining engineer), carried out laboratory tests and processed measurement results. 